American Journal of Biochemistry and Biotechnology 4 (1): 7-18, 2008

ISSN 1553-3468

(C) 2008 Science Publications

\title{
Heat Balance Analysis During the Production of Jadomycin C
}

\author{
T. J. Burdock, A. H. Giffin, M.S. Brooks and A.E. Ghaly \\ Department of Process Engineering and Applied Science, Dalhousie University, \\ Halifax, Nova Scotia, Canada B3J 2X4
}

\begin{abstract}
Jadomycins are novel antibiotics that exhibit biological activity against bacteria and yeast and also demonstrate cytotoxicity against cancer cells. Jadomycin C was successfully produced from $10 \mathrm{~L}$ of fermentation media in a $19 \mathrm{~L}$ bioreactor using Streptomyces venezuelae ISP5230 which was shocked with ethanol. The bioreactor temperature and $\mathrm{pH}$ were successfully maintained at $30^{\circ} \mathrm{C}$ and 7 , respectively. The heat of mixing from the agitator was $4.9 \mathrm{~J} \cdot \mathrm{s}^{-1}$. The heat of metabolism was $4.4 \mathrm{~J} \cdot \mathrm{s}^{-1}$ and the heat provided by the water circulator was $6.2 \mathrm{~J} \cdot \mathrm{s}^{-1}$ during the fermentation. A substantial portion of heat $(26.45 \%)$ was lost with the exhaust air leaving the bioreactor, while $69.03 \%$ was lost through the walls and $1.94 \%$ and $2.85 \%$ were lost through the top and bottom of the bioreactor. Once the bioreactor was inoculated, there was no lag period evident and a specific growth rate of $0.23 \mathrm{~h}^{-1}$ was achieved. The rate of jadomycin production initially increased rapidly and reached a maximum level within 15 hours after the ethanol shock. The dissolved oxygen (DO) concentration during the experiment was inversely related to the growth of the bacteria.
\end{abstract}

Keywords: Heat balance, fermentation, jadomycin, Streptomyces venezuelae, dissolved oxygen, temperature, $\mathrm{pH}$.

\section{INTRODUCTION}

Jadomycins are a group of antibiotics that are produced by Streptomyces venezuelae ISP5230. They exhibit biological activity against bacteria and yeast and also demonstrate cytotoxicity against cancer cells ${ }^{[1]}$. Jadomycin production can be induced by culturing the bacteria in a specific nutritional environmental and by shocking the bacteria with ethanol. Amino acids must be present in the jadomycin production media as they are incorporated to form part of the jadomycin molecule. Different types of jadomycin can be produced, depending on the amino acids available ${ }^{[2]}$. Examples are jadomycin B from isoleucine and jadomycin $\mathrm{C}$ from glycine (Fig. 1). Jadomycins have been produced using laboratory-scale fermentations typically involving culture volumes of less than $250 \mathrm{~mL}^{[2-7]}$. However, there have been no studies using larger-scale bioreactors for producing jadomycin.

An important aspect of any fermentation is the control of environmental parameters such as temperature to provide the optimal conditions for microbial growth and product formation. Past research determining optimal conditions for jadomycin production have varied fermentation parameters such as media composition and ethanol shock conditions while keeping the fermentation temperature at $30^{\circ} \mathrm{C}^{[2,6]}$. Heat balances can therefore be used to determine the amount of heat generated or lost from the bioreactor. They can also be used to predict the heating and cooling requirements of a system ${ }^{[8,9]}$.

The purpose of this study was to conduct a heat balance on a $19 \mathrm{~L}$ capacity bioreactor during the batch production of jadomycin $\mathrm{C}$. The specific objectives were to determine: (a) the heat gain (heat of mixing, heat of metabolism and heat provided by the water circulator) and (b) the heat losses from the bioreactor (through the top, bottom and walls of the bioreactor and with the exhaust gas).

\section{MATERIALS AND METHODS}

Experimental Apparatus: The fermentation system (Fig. 2) consisted of a bioreactor with temperature measurement and $\mathrm{pH}$ control (model NLF, Bioengineering, $\mathrm{CH}-8636$ Wald, Switzerland) and heating and air supply systems.

Corresponding author: Su-Ling Brooks, Department of Process Engineering and Applied Science, Dalhousie University, Halifax, Nova Scotia, Canada B3J 2X4, Tel: (902) 494-6482. 
<smiles>CCC(C)C1C(=O)OC2c3cc(C)cc(O)c3C3=C(C(=O)c4c(OC5CC(O)C(O)C(C)O5)cccc4C3=O)N21</smiles>

Jadomycin $\mathrm{B}\left(\mathrm{C}_{30} \mathrm{H}_{31} \mathrm{NO}_{9}\right)$<smiles>Cc1cc(O)c2c(c1)C1OC(=O)CN1C1=C2C(=O)c2c(OC3CC(O)C(O)C(C)O3)cccc2C1=O</smiles>

Jadomycin $\mathrm{C}\left(\mathrm{C}_{26} \mathrm{H}_{23} \mathrm{NO}_{9}\right)$<smiles>CCC(C)C(N)C(=O)O</smiles>

Isoleucine



Fig. 1: Molecular structures for jadomycins and corresponding amino acids ${ }^{[6]}$

The bioreactor was fabricated from stainless steel and had an overall capacity of $19 \mathrm{~L}$. A pH probe (13-620299, Fisher Scientific, Ottawa, Ontario, Canada) was connected to the bioreactor controller. Peristaltic pumps (7018, Cole Palmer, Chicago, Illinois, USA) were used to add $3 \mathrm{M} \mathrm{HCl}$ or $3 \mathrm{M} \mathrm{NaOH}$, as required for $\mathrm{pH}$ control. The $\mathrm{pH}$ reading was displayed on the bioreactor control box. The temperature probe was connected to the controller box which displayed the temperature reading. A circulating waterbath water circulator (Series 8000, Polyscience, Niles, Illinois, USA) was used to control the temperature in the bioreactor. A pressure regulator (AW20-NOH-CZ, Industrial Supplies Ltd, Dartmouth, Nova Scotia, Canada) was used to regulate the university supply compressed air. A flow meter (C-03219, Cole Palmer, Niles, Illinois, USA) was used measure the air flow rate through the bioreactor. This was set to $28.5 \mathrm{~L} \cdot \mathrm{min}^{-1}$. The air was passed through a $0.45 \mu \mathrm{m}$ PTFE/PP filter (SLFH 050-10, Fisher Scientific, Ottawa, Ontario,
Canada) and was released near the bottom of the bioreactor through a sparger (fabricated in the department machine shop) attached to the end of a metal tube that extended from the top to the bottom of the bioreactor. The dissolved oxygen (DO) was measured with a DO probe and meter (model 407510, Extech Instruments, Waltham, Massachusetts, USA).

Reagents: The maltose and MOPS buffer were obtained from Sigma (Oakville, Ontario, Canada). The yeast extract, malt extract, and agar were obtained from Difco (Lawrence, Kansas, USA). The glycine was obtained from Bio-Rad Laboratories (Mississauga, Ontario, Canada). The sodium chloride was obtained from EM Science (Lawrence, Kansas, USA). Potassium phosphate, magnesium sulfate, ferrous sulfate, calcium chloride, zinc sulfate, boric acid, ammonium molybdate, and glucose were obtained from Fisher Scientific (Ottawa, Ontario, Canada). 


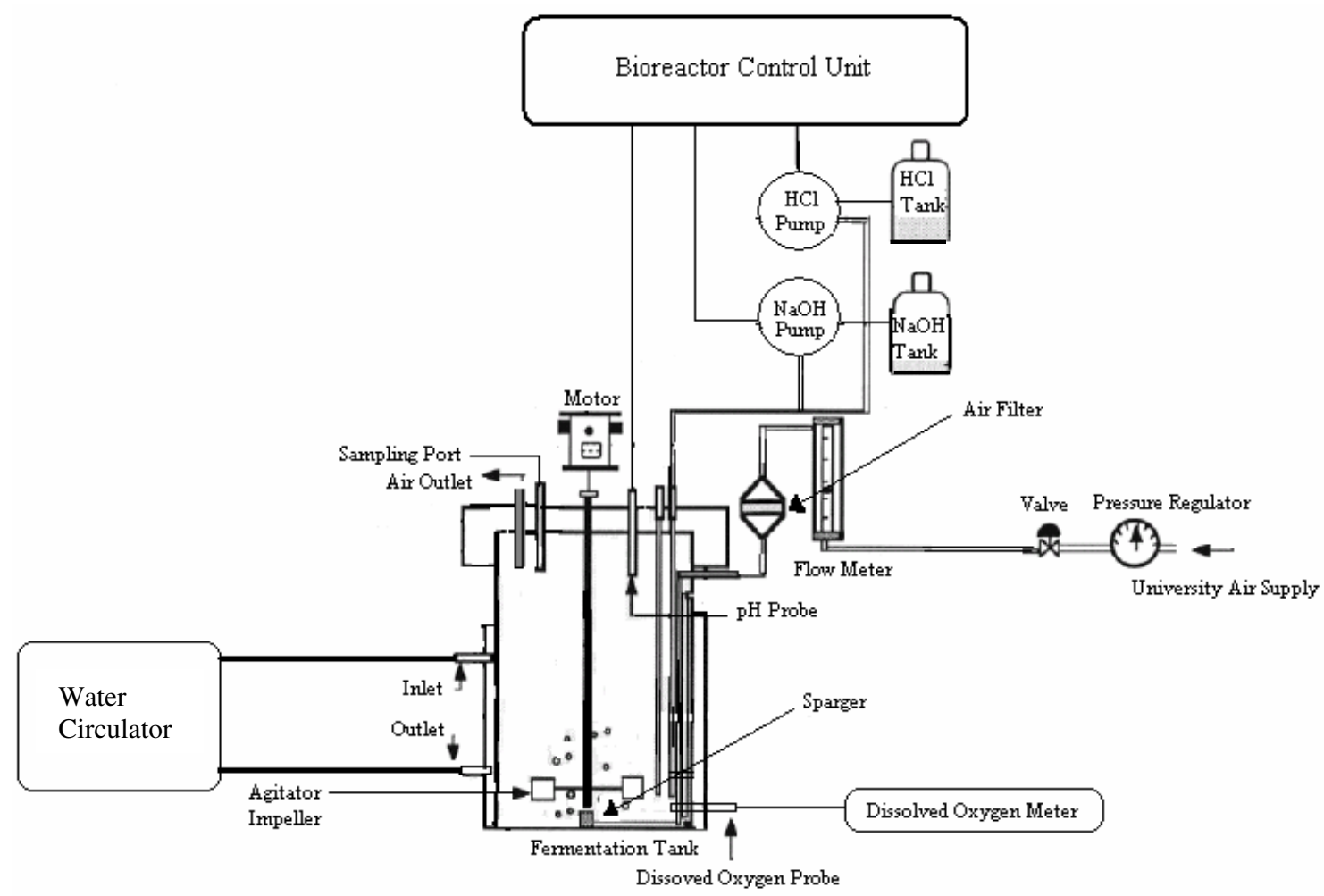

Fig. 2: Schematic diagram of the fermentation system

Table 1: Composition of media used for Streptomyces venezuelae ISP5230 growth and jadomycin C production

\begin{tabular}{|c|c|c|}
\hline Media Component & Chemical Formula & Amount $^{\mathrm{a}}$ \\
\hline \multicolumn{3}{|l|}{ GROWTH MEDIUM } \\
\hline Maltose & $\mathrm{C}_{12} \mathrm{H}_{22} \mathrm{O}_{11}$ & $4.0 \mathrm{~g}$ \\
\hline Yeast Extract & & $4.0 \mathrm{~g}$ \\
\hline Malt Extract & & $10.0 \mathrm{~g}$ \\
\hline Agar & & $15.0 \mathrm{~g}$ \\
\hline MOPS & $\mathrm{C}_{7} \mathrm{H}_{15} \mathrm{NO}_{4} \mathrm{~S}$ & $1.9 \mathrm{~g}$ \\
\hline \multicolumn{3}{|l|}{ PRODUCTION MEDIUM } \\
\hline \multicolumn{3}{|l|}{ MSM Solution: } \\
\hline Magnesium Sulfate & $\mathrm{MgSO}_{4}$ & $0.4 \mathrm{~g}$ \\
\hline MOPS & $\mathrm{C}_{7} \mathrm{H}_{15} \mathrm{NO}_{4} \mathrm{~S}$ & $1.9 \mathrm{~g}$ \\
\hline Salt Solution: & & $9.0 \mathrm{~mL}$ \\
\hline Sodium Chloride ( $1 \% \mathrm{w} / \mathrm{v}$ salt solution) & $\mathrm{NaCl}$ & \\
\hline Calcium Chloride ( $1 \%$ w/v salt solution) & $\mathrm{CaCl}_{2}$ & \\
\hline Ferrous Sulfate $(0.2 \% \mathrm{w} / \mathrm{v}$ ferrous sulfate solution $)$ & $\mathrm{FeSO}_{4} \cdot 7 \mathrm{H}_{2} \mathrm{O}$ & $4.5 \mathrm{~mL}$ \\
\hline Trace Mineral Solution: & & $4.0 \mathrm{~mL}$ \\
\hline Zinc Sulfate $(88 \%$ w/v trace mineral solution) & $\mathrm{ZnSO}_{4} \cdot 7 \mathrm{H}_{2} \mathrm{O}$ & \\
\hline Cupric Sulfate $(3.9 \% \mathrm{w} / \mathrm{v}$ trace mineral solution) & $\mathrm{CuSO}_{4} \cdot 5 \mathrm{H}_{2} \mathrm{O}$ & \\
\hline Manganese Sulfate $(0.61 \%$ w/v trace mineral solution) & $\mathrm{MnSO}_{4} \cdot 4 \mathrm{H}_{2} \mathrm{O}$ & \\
\hline Boric Acid $(0.57 \%$ trace mineral solution $)$ & $\mathrm{H}_{3} \mathrm{BO}_{3}$ & \\
\hline Ammonium Molybdate ( $0.37 \%$ trace mineral solution) & $\left(\mathrm{NH}_{4}\right)_{6} \cdot 4 \mathrm{H}_{2} \mathrm{O}$ & \\
\hline \multicolumn{3}{|l|}{ GM Solution: } \\
\hline Glucose (dextrose) & $\mathrm{C}_{6} \mathrm{H}_{12} \mathrm{O}_{6}$ & $5.4 \mathrm{~g}$ \\
\hline \multicolumn{3}{|l|}{ Phosphate Stock Solution $(9 \mathrm{mM})$ : } \\
\hline Potassium Phosphate & $\mathrm{K}_{2} \mathrm{HPO}_{4}$ & $10.5 \mathrm{~g}$ \\
\hline Potassium Phosphate Monobasic & $\mathrm{KH}_{2} \mathrm{PO}_{4}$ & $4.5 \mathrm{~g}$ \\
\hline \multicolumn{3}{|l|}{ Amino Acid: } \\
\hline Glycine & $\mathrm{C}_{2} \mathrm{H}_{5} \mathrm{NO}_{2}$ & $4.5 \mathrm{~g}$ \\
\hline
\end{tabular}

${ }^{a}$ per $\mathrm{L}$ of distilled water 
Media Preparation: Prior to the production of jadomycin in the bioreactor, an innoculum of $S$. venezuelae ISP5230 was prepared with maltose, yeast and malt extract (MYM) growth media according to the method described by Jakeman et $\mathrm{al}^{[6]}$. To prepare MYM agar, $4 \mathrm{~g}$ of maltose, $4 \mathrm{~g}$ of yeast extract, $10 \mathrm{~g}$ of malt extract, and $15 \mathrm{~g}$ of agar were dissolved in $1 \mathrm{~L}$ of distilled water by heating and mixing. MYM broth was prepared by adding $4 \mathrm{~g}$ of maltose, $4 \mathrm{~g}$ of yeast extract, $10 \mathrm{~g}$ of malt extract, and $1.9 \mathrm{~g}$ of MOPS buffer to $1 \mathrm{~L}$ of distilled water and mixing until dissolved. The production media (MSM solution) was prepared by adding $0.4 \mathrm{~g}$ of magnesium sulfate, $1.9 \mathrm{~g}$ of MOPS buffer, $9 \mathrm{~mL}$ of salt solution, $4 \mathrm{~mL}$ of ferrous sulfate, $4.5 \mathrm{~mL}$ of trace mineral solution, and $4.5 \mathrm{~g}$ of glycine. The salt solution was prepared by dissolving $0.001 \mathrm{~g}$ each of sodium chloride and calcium chloride in $100 \mathrm{~mL}$ of distilled water. The ferrous sulfate solution was made by dissolving $0.0001 \mathrm{~g}$ of ferrous sulfate in $50 \mathrm{~mL}$ of distilled water. The trace mineral solution was made by dissolving $0.088 \mathrm{~g}$ of zinc sulfate, $0.0039 \mathrm{~g}$ of cupric sulfate, $0.00061 \mathrm{~g}$ of manganese sulfate, $0.00057 \mathrm{~g}$ of boric acid, and $0.00037 \mathrm{~g}$ of ammonium molybdate in $100 \mathrm{~mL}$ of distilled water. The phosphate stock solution was prepared by dissolving $5.384 \mathrm{~g}$ of potassium phosphate and $2.311 \mathrm{~g}$ of potassium phosphate monobasic in $100 \mathrm{~mL}$ of distilled water. The glucose solution was prepared by dissolving $53.5 \mathrm{~g}$ of glucose in $180 \mathrm{~mL}$ of distilled water. All solutions were autoclaved. MYM agar was used in 40 petrie dishes for streaking. The MYM broth was distributed evenly amongst twenty $250 \mathrm{~mL}$ Erlenmeyer flasks for growing the bioreactor innoculum.

A total working volume of $10 \mathrm{~L}$ was used in the bioreactor; therefore $9 \mathrm{~L}$ of production media was prepared. The production media consisted of MSM solution, GM solution, and glycine for the amino acid (Table 1). The MSM solution and glycine were autoclaved together while the glucose and phosphate solutions were each autoclaved separately to avoid precipitation. All media were autoclaved at $121^{\circ} \mathrm{C}$ for 15 minutes.

Innoculum Preparation: A culture of S. venezuelae ISP5230 grown on MYM agar was obtained from the Jakeman Laboratory, Faculty of Pharmacy, Dalhousie University. Forty petrie dishes containing MYM agar were streaked with the bacteria and placed in an incubator at $30^{\circ} \mathrm{C}$ for 48 hours. Colonies from two petrie dishes were then scraped into an Erlenmyer flask containing $50 \mathrm{~mL}$ MYM broth. The twenty flasks were capped with foam plugs, covered with tinfoil and then placed in a shaking incubator (Series 25 Incubator Shaker, New Brunswick Scientific, Edison, New Jersey, USA) at $30^{\circ} \mathrm{C}$ and $250 \mathrm{rpm}$ for 22 hours.

Experimental Protocol: Before the start of any experiments, the internal surfaces of the bioreactor and all attachments were first washed with soap and hot water, rinsed and then sterilized with sodium metabisulfite solution $\left(12.5 \mathrm{~g} \cdot \mathrm{L}^{-1}\right)$.

Four initial experiments were conducted using $10 \mathrm{~L}$ of water in the bioreactor. The experimental conditions are summarized in Table 2. The first experiment was carried out at room temperature with the agitator running at $250 \mathrm{rpm}$ with no air supplied to determine the heat of mixing. In the second experiment, the water was maintained at $30^{\circ} \mathrm{C}$ using the circulator and no air or agitation were used. This experiment was used to calculate the heat required to maintain the temperature at $30^{\circ} \mathrm{C}$. In the third experiment, no air was used and the temperature and mixing speed were maintained at $30^{\circ} \mathrm{C}$ and $250 \mathrm{rpm}$, respectively. This experiment was used to calculate the heat input and heat losses under anaerobic conditions. In the fourth experiment, the temperature, mixing speed, and air flow were maintained at $30^{\circ} \mathrm{C}, 250 \mathrm{rpm}$ and $28.5 \mathrm{~L} \cdot \mathrm{min}^{-1}$, respectively. This was used to calculate the heat requirement and heat losses under aerobic conditions.

For the fermentation experiment, the bioreactor was filled with $9 \mathrm{~L}$ of production media. The temperature, agitator speed, air flow rate and $\mathrm{pH}$ were set at $30^{\circ} \mathrm{C}, 250 \mathrm{rpm}, 28.5 \mathrm{~L} \cdot \mathrm{min}^{-1}$ and 7 , respectively. The system was left running until steady state conditions were achieved (no change in temperatures). The innoculum $(1 \mathrm{~L})$ was added aseptically through a port in the bioreactor lid. Temperature readings and samples were taken from the bioreactor every 30 minutes. The absorbance of the samples was measured at $600 \mathrm{~nm}$ using a spectrophotometer (Genesys 20, Thermo Electron Corporation, Waltham, Massachusetts, USA), as described by Jakeman et $\mathrm{al}^{[6]}$. When the bacterial growth resulted in an absorbance reading of 0.7 , the system was shocked with ethanol. This was achieved by adding $300 \mathrm{~mL}$ of absolute ethanol $(3 \% \mathrm{v} / \mathrm{v})$ to the bioreactor through a septum in the lid via a needle and syringe. After the ethanol shock, temperature readings and samples were taken every hour. Samples were centrifuged at $6,000 \mathrm{rpm}$ for 25 minutes and the absorbance of the supernatant was measured at $526 \mathrm{~nm}$ to monitor jadomycin production $^{[6]}$. 
Table 2: Summary of experimental conditions

\begin{tabular}{ccccc}
\hline Experiment & Bioreactor Contents & $\begin{array}{c}\text { Water Temperature } \\
\left({ }^{\circ} \mathrm{C}\right)\end{array}$ & $\begin{array}{c}\text { Agitator Speed } \\
(\mathrm{rpm})\end{array}$ & $\begin{array}{c}\text { Air Flow Rate } \\
\left(\mathrm{L} \cdot \mathrm{min}^{-1}\right)\end{array}$ \\
\hline 1 & Water & room & 250 & - \\
2 & Water & 30 & 0 & - \\
3 & Water & 30 & 250 & - \\
4 & Water & 30 & 250 & 28.5 \\
5 & $\begin{array}{l}\text { Production media with } \\
\text { S.venezulae ISP5230 }\end{array}$ & 30 & 250 & 28.5 \\
\hline
\end{tabular}

${ }^{\mathrm{b}}$ The bacteria were shocked with ethanol after 5 hours of growth

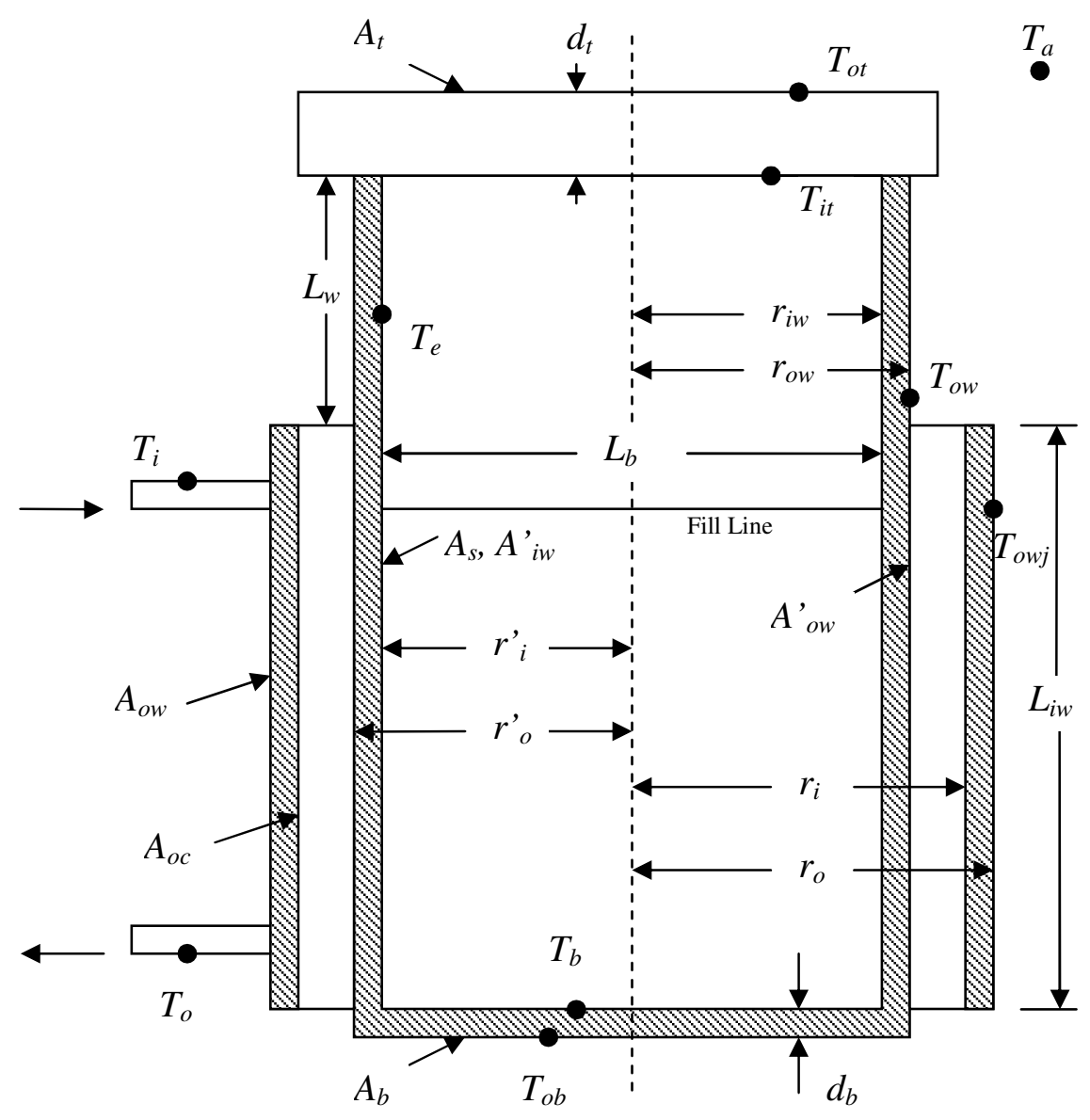

Fig. 3: Schematic of bioreactor dimensions and temperature measurement locations 
Heat Balance: Several temperatures were measured at ten locations on the bioreactor (Fig. 3). These were: (a) ambient temperature, (b) jacket inlet water temperature, (c) jacket outlet water temperature, (d) wall surface temperature without jacket, (e) wall surface temperature with jacket, (f) external floor temperature, (g) external top temperature, (h) exhaust temperature, (i) top fluid temperature, and (j) bottom fluid temperature. The bottom fluid temperature $\left(T_{b}\right)$ was measured with the bioreactor temperature probe and type $\mathrm{K}$ thermocouples were used to measure the remaining temperatures.

The heat balance over the bioreactor system included: (a) the heat supplied by the constant temperature circulator, (b) the heat generated by mixing, (c) the heat generated by microbial metabolism, (d) the heat lost through the exhaust gas, (e) the heat lost through the fermenter bottom, (f) the heat lost through the fermenter top, and (g) the heat lost through the fermenter walls. Enthalpy changes from the addition of acid/base to control the $\mathrm{pH}$ during fermentation were neglected. The overall heat balance equation can be represented as:

$$
q_{s}+q_{m}+q_{y}=q_{a}+q_{b}+q_{t}+q_{w j}+q_{w}
$$

Where:

$$
\begin{aligned}
& q_{s}=\text { heat supplied by the circulator to bioreactor }\left(\mathrm{J} \cdot \mathrm{s}^{-1}\right) \\
& q_{m}=\text { heat generated by mixing }\left(\mathrm{J} \cdot \mathrm{s}^{-1}\right) \\
& q_{y}=\text { heat generated by metabolism }\left(\mathrm{J} \cdot \mathrm{s}^{-1}\right) \\
& q_{a}=\text { heat lost with exhaust gas }\left(\mathrm{J} \cdot \mathrm{s}^{-1}\right) \\
& q_{b}=\text { heat lost through fermenter bottom }\left(\mathrm{J} \cdot \mathrm{s}^{-1}\right) \\
& q_{t}=\text { heat lost through lid }\left(\mathrm{J} \cdot \mathrm{s}^{-1}\right) \\
& q_{w}=\text { heat lost through wall without heating jacket } \\
& q_{w j}=\left(\mathrm{J} \cdot \mathrm{s}^{-1}\right)
\end{aligned}
$$

With reference to Fig. 3, the values of the heat losses $q_{a}, q_{b}, q_{b}, q_{w}$, and $q_{w j}$ can be calculated using Eq.s 2-6:

$$
\begin{aligned}
& q_{a}=Q_{a} C_{p a}\left(T-T_{a}\right) \\
& q_{b}=U_{b} A_{b}\left(T_{b}-T_{a}\right) \\
& q_{t}=U_{t} A_{t}\left(T-T_{a}\right) \\
& q_{w}=U_{w} A_{w}\left(T_{e}-T_{a}\right) \\
& q_{w j}=U_{w j} A_{w j}\left(T_{f}-T_{a}\right)
\end{aligned}
$$

Where:

$$
\begin{aligned}
A_{b}= & \text { surface area of fermenter bottom }\left(\mathrm{m}^{2}\right) \\
A_{t}= & \text { surface area of fermenter lid }\left(\mathrm{m}^{2}\right) \\
A_{w}= & \text { surface area of fermenter wall without heat jacket } \\
& \left(\mathrm{m}^{2}\right) \\
A_{w j}= & \begin{array}{l}
\text { surface area of fermenter wall with heat jacket } \\
\left(\mathrm{m}^{2}\right)
\end{array}
\end{aligned}
$$

$$
\begin{aligned}
C_{p a}= & \text { specific heat of exhaust air }\left(\mathrm{J} \cdot \mathrm{kg}^{-1} \cdot \mathrm{K}^{-1}\right) \\
Q_{a}= & \text { mass flow rate of exhaust out of the system } \\
& \left(\mathrm{kg} \cdot \mathrm{s}^{-1}\right) \\
T= & \text { temperature at interface between liquid medium } \\
& \text { and exhaust air }\left({ }^{\circ} \mathrm{C}\right) \\
T_{a}= & \text { ambient air temperature }\left({ }^{\circ} \mathrm{C}\right) \\
T_{b}= & \text { temperature at interface between fermenter floor } \\
& \text { and liquid }\left({ }^{\circ} \mathrm{C}\right) \\
T_{e}= & \text { temperature at the interface between fermenter } \\
& \text { wall and headspace gas }\left({ }^{\circ} \mathrm{C}\right) \\
T_{f}= & \text { temperature at the interface between fermenter } \\
& \text { wall and liquid medium }\left({ }^{\circ} \mathrm{C}\right) \\
U_{b}= & \text { overall heat loss coefficient of fermenter bottom } \\
& \left(\mathrm{J} \cdot \mathrm{m}^{-2} \cdot \mathrm{s}^{-1} \cdot \mathrm{K}^{-1}\right) \\
U_{t}= & \text { overall heat loss } \operatorname{coefficient} \text { of fermenter top } \\
& \left(\mathrm{J} \cdot \mathrm{m}^{-2} \cdot \mathrm{s}^{-1} \cdot \mathrm{K}^{-1}\right) \\
U_{w}= & \text { overall heat loss } \operatorname{coefficient} \text { of fermenter wall } \\
& \text { without heat jacket }\left(\mathrm{J} \cdot \mathrm{m}^{-2} \cdot \mathrm{s}^{-1} \cdot \mathrm{K}^{-1}\right) \\
U_{w j}= & \text { overall heat loss } \operatorname{coefficient~of~fermenter~wall~} \\
& \text { with the heat jacket }\left(\mathrm{J} \cdot \mathrm{m}^{-2} \cdot \mathrm{s}^{-1} \cdot \mathrm{K}^{-1}\right)
\end{aligned}
$$

The overall heat transfer coefficient of the bioreactor bottom $\left(U_{b}\right)$ can be calculated as follows ${ }^{[10]}$ :

$$
U_{b}=\frac{1}{\left(\frac{d_{b}}{k_{b}}\right)+\left(\frac{1}{h_{i b}}\right)+\left(\frac{1}{h_{o b}}\right)}
$$

Where:

$$
\begin{aligned}
d_{b}= & \text { floor thickness }(\mathrm{m}) \\
h_{i b}= & \text { convective heat transfer between the medium and } \\
& \text { inner surface of fermenter bottom }\left(\mathrm{J} \cdot \mathrm{m}^{-2} \cdot \mathrm{s}^{-1} \cdot \mathrm{K}^{-1}\right) \\
h_{o b}= & \text { convective heat transfer coefficient between outer } \\
& \text { surface of fermenter bottom and ambient } \\
& \text { temperature }\left(\mathrm{J} \cdot \mathrm{m}^{-2} \cdot \mathrm{s}^{-1} \cdot \mathrm{K}^{-1}\right) \\
k_{b}= & \text { thermal conductivity of the bottom }\left(\mathrm{J} \cdot \mathrm{m}^{-1} \cdot \mathrm{s}^{-1} \cdot \mathrm{K}^{-1}\right)
\end{aligned}
$$

In experiments when the bioreactor medium is being stirred with the agitator, the heat transfer to the fermenter floor from the medium is by forced convection. Heat transfer from the surrounding air to the fermenter floor occurs by natural convection. Thus, the heat transfer coefficient due to forced convection $\left(h_{i b}\right)$ can be neglected since it is much larger than that of the heat transfer coefficient due to natural convection $\left(h_{o b}\right)^{[8]}$. Therefore, Eq.7 can be rewritten as:

$$
U_{b}=\frac{1}{\left(\frac{d_{b}}{k_{b}}\right)+\left(\frac{1}{h_{o b}}\right)}
$$

The convective heat transfer coefficient $\left(h_{o b}\right)$ for a heated plate facing downward can be calculated as follows ${ }^{[10]}$ : 


$$
h_{o b}=0.59\left(\frac{T_{o b}-T_{a}}{L_{b}}\right) 0.25
$$

Where:

$$
\begin{aligned}
L_{b}= & \text { characteristic length, diameter for a circle }(\mathrm{m}) \\
T_{o b}= & \text { temperature of the outside surface of the } \\
& \text { fermenter bottom }\left({ }^{\circ} \mathrm{C}\right)
\end{aligned}
$$

The overall heat transfer coefficient of the bioreactor top $\left(U_{t}\right)$ can be calculated from the following equation $^{[10]}$ :

$$
U_{t}=\frac{1}{\left(\frac{d_{t}}{k_{t}}\right)+\left(\frac{1}{h_{g}}\right)+\left(\frac{1}{h_{o t}}\right)}
$$

Where:

$$
\begin{aligned}
d_{t}= & \text { thickness of the lid }(\mathrm{m}) \\
k_{t}= & \text { thermal conductivity of the lid }\left(\mathrm{J} \cdot \mathrm{m}^{-1} \cdot \mathrm{s}^{-1} \cdot \mathrm{K}^{-1}\right) \\
h_{g}= & \text { convective heat transfer coefficient between gas } \\
& \text { and inner surface of the lid }\left(\mathrm{J} \cdot \mathrm{m}^{-2} \cdot \mathrm{s}^{-1} \cdot \mathrm{K}^{-1}\right) \\
h_{o t}= & \text { convective heat transfer } \operatorname{coefficient} \text { between } \\
& \text { surface of the lid and ambient air }\left(\mathrm{J} \cdot \mathrm{m}^{-2} \cdot \mathrm{s}^{-1} \cdot \mathrm{K}^{-1}\right)
\end{aligned}
$$

The convective heat transfer coefficient relating to the gas and the inner surface of the bioreactor lid $\left(h_{g}\right)$ can be calculated from Eq.11 or Eq.12 depending on the experimental conditions ${ }^{[10]}$. Eq.11 is appropriate when there is no forced air flow through the system (experiments 1-3, Table 2), as it is based on natural convection due to a cooled plate facing downward. Eq.12 can be used when there is air flowing through the system, during forced convection (experiment 4, Table 2).

$$
\begin{aligned}
& h_{g}=1.32\left(\frac{T-T_{i t}}{L_{t}}\right)^{0.25} \\
& h_{g}=\frac{N u k_{a}}{L_{t}}
\end{aligned}
$$

Where:

$$
\begin{aligned}
k_{a}= & \text { thermal conductivity of air }\left(\mathrm{J} \cdot \mathrm{m}^{-1} \cdot \mathrm{s}^{-1} \cdot \mathrm{K}^{-1}\right) \\
L_{t}= & \text { characteristic length, diameter for a disk }(\mathrm{m}) \\
N u= & \text { Nusselt number } \\
T_{i t}= & \text { temperature at the interface between the } \\
& \text { headspace gas and the inner surface of the } \\
& \text { bioreactor lid }\left({ }^{\circ} \mathrm{C}\right)
\end{aligned}
$$

The Nusselt number is calculated with the following equation $^{[10]}$ :

$$
N u=0.664 \operatorname{Re}^{1 / 2} \operatorname{Pr}^{1 / 3}
$$

Where:

$$
\begin{aligned}
& R e=\text { Reynolds number } \\
& \operatorname{Pr}=\text { Prandtl number }
\end{aligned}
$$

The overall convective heat transfer coefficient between the lid and the ambient air $\left(h_{o t}\right)$ is found using the natural convection correlation for a heated plate facing upward $^{[10]}$ :

$h_{o t}=0.59\left(\frac{T_{o t}-T_{a}}{L_{t}}\right)^{1 / 4}$

Where:

$$
T_{o t}=\text { temperature at the outer surface of the top }\left({ }^{\circ} \mathrm{C}\right)
$$

The overall heat transfer coefficient of the section of the bioreactor wall without the heating jacket $\left(U_{w}\right)$ can be calculated with Eq. $15^{[10]}$.

$$
U_{w}=\frac{1}{A_{w} \ln \left(\frac{r_{o w}}{r_{i w}}\right)+\left(\frac{1}{h_{o w}}\right)}
$$

Where:

$$
\begin{aligned}
& \begin{aligned}
A_{w}= & \text { surface area of the fermenter wall }\left(\mathrm{m}^{2}\right) \\
h_{o w}= & \text { convective heat transfer coefficient between the } \\
& \text { outer wall of the fermenter and the ambient air } \\
& \left(\mathrm{J} \cdot \mathrm{m}^{-2} \cdot \mathrm{s}^{-1} \cdot \mathrm{K}^{-1}\right)
\end{aligned} \\
& k_{w}= \text { thermal conductivity of the fermenter wall } \\
&\left(\mathrm{J} \cdot \mathrm{m}^{-1} \cdot \mathrm{s}^{-1} \cdot \mathrm{K}^{-1}\right) \\
& L_{w}= \text { vertical height of the section of fermenter wall } \\
& \text { without the heating jacket }(\mathrm{m})
\end{aligned}
$$

The convective heat transfer coefficient between the ambient air and the outer surface of the bioreactor $\left(h_{o w}\right)$ can be calculated using the equation for natural convection over a vertical cylinder ${ }^{[10]}$.

$$
h_{o w}=1.42\left(\frac{T_{o w}-T_{a}}{L_{w}}\right)^{0.25}
$$

Where:

$$
\begin{aligned}
T_{o w}= & \text { temperature of outer surface of the bioreactor } \\
& \text { without the heat jacket }\left({ }^{\circ} \mathrm{C}\right)
\end{aligned}
$$

The section of the bioreactor wall which is surrounded by the heating jacket has its own overall heat transfer coefficient $\left(U_{w j}\right)$ which changes depending on the experimental conditions. The overall equation can be written as follows ${ }^{[8]}$ : 
Am. J. Biochem. \& Biotech., 4 (1): 7-18, 2008

$$
U_{w j}=\frac{1}{\left.A_{o w}^{\prime} \ln \left(\frac{r_{o}^{\prime}}{r_{i}^{\prime}}\right)+\left(\frac{A_{o c} \ln \left(\frac{r_{i}}{r_{o}^{\prime}}\right)}{2 \pi k_{w} L_{w j}}\right)+\frac{A_{o w} \ln \left(\frac{r_{o}}{r_{i}}\right)}{2 \pi k_{h} L_{w j} j}\right)+\left(\frac{A_{o w}^{\prime}}{2 \pi k_{w} L_{w j}}\right)\left(\frac{1}{A_{i w}^{\prime}}\right)+\left(\frac{1}{h_{i v j}^{\prime}}\right)}
$$

Where:

$$
\begin{aligned}
A^{\prime}{ }_{i w}= & \text { surface area of the inner side of the fermenter } \\
& \text { wall }\left(\mathrm{m}^{2}\right) \\
A_{o c}= & \text { surface area of the inner side of the heating jacket } \\
& \text { wall }\left(\mathrm{m}^{2}\right) \\
A_{o w}= & \text { surface area of outer side of the heating jacket } \\
& \text { wall }\left(\mathrm{m}^{2}\right) \\
A^{\prime}{ }_{o w}= & \text { surface area of the outer side of the fermenter } \\
& \text { wall }\left(\mathrm{m}^{2}\right) \\
h^{\prime}{ }_{i w j}= & \text { convective heat transfer coefficient between } \\
& \text { medium and the inner side of the fermenter wall } \\
& \left(\mathrm{J} \cdot \mathrm{m}^{-2} \cdot \mathrm{s}^{-1} \cdot \mathrm{K}^{-1}\right) \\
h_{o w j}= & \text { convective heat transfer coefficient between the } \\
& \text { outer side of the heat jacket wall and the ambient } \\
& \text { air }\left(\mathrm{J} \cdot \mathrm{m}^{-2} \cdot \mathrm{s}^{-1} \cdot \mathrm{K}^{-1}\right) \\
k_{h}= & \text { thermal conductivity of the heating liquid } \\
& \left(\mathrm{J} \cdot \mathrm{m}^{-1} \cdot \mathrm{s}^{-1} \cdot \mathrm{K}^{-1}\right) \\
L_{w j}= & \text { vertical height of wall surrounded by heating } \\
& \text { jacket }(\mathrm{m}) \\
r_{i}= & \text { inner radius of heat jacket wall }(\mathrm{m}) \\
r_{o}= & \text { outer radius of heat jacket wall }(\mathrm{m}) \\
r_{i}^{\prime}= & \text { inner radius of fermenter wall }(\mathrm{m}) \\
r^{\prime}= & \text { outer radius of fermenter wall }(\mathrm{m})
\end{aligned}
$$

If the system is not agitated, the heat transfer between the medium and the fermenter wall is by free convection, as is the transfer between the outer jacket wall and the ambient air. Thus, the variables $h_{\text {owj }}$ and $h^{\prime}{ }_{i w j}$ in Eq.17 can be found using the equation for free convection over a vertical cylinder or plate ${ }^{[10]}$ :

$h_{o w j}=1.42\left(\frac{T_{o w j}-T_{a}}{L_{w j}}\right)^{0.25}$

$h_{i w j}^{\prime}=1.42\left(\frac{\left(\frac{T_{O}+T_{i}}{2}\right)-T_{f}}{L_{w j}}\right)^{0.25}$

Where:

$T_{\text {owj }}=$ temperature of outer surface of the heating jacket wall $\left({ }^{\circ} \mathrm{C}\right)$

$T_{m}=$ temperature of the bulk fluid in the bioreactor $\left({ }^{\circ} \mathrm{C}\right)$

If the temperature circulator is in operation without the agitator (experiment 2, Table 2), the term that deals with heat transfer through the stagnant layer of fluid in the jacket can be removed and Eq.17 can be written as follows:

$$
U_{w j}=\frac{1}{A_{o w}^{\prime} \ln \left(\frac{r_{o}^{\prime}}{r_{i}^{\prime}}\right)+\left(\frac{A_{o w} \ln \left(\frac{r_{o}}{r_{i}}\right)}{2 \pi k_{w} L_{w j}}\right)+\left(\frac{A_{o w}^{\prime}}{A_{i w}^{\prime}}\right)\left(\frac{1}{h_{i w j}^{\prime}}\right)+\left(\frac{1}{h_{o w j}}\right)}
$$

If the agitator is operating but circulator is not operational (experiment 1, Table 2), the heat transfer between the medium and the fermenter wall is by forced convection. Since the forced convection term $\left(h^{\prime}{ }_{i w j}\right)$ will be much larger than the natural convection term $\left(h_{\text {owj }}\right)$ it can be neglected, and Eq.17 can be rewritten as follows:

$$
U_{w j}=\frac{1}{A_{o w}^{\prime} \ln \left(\frac{r_{o}^{\prime}}{r_{i}^{\prime}}\right)+\left(\frac{A_{o c} \ln \left(\frac{r_{i}}{r_{o}^{\prime}}\right)}{2 \pi k k_{w} L_{w j}}\right)+\left(\frac{A_{o w} \ln \left(\frac{r_{o}}{r_{i}}\right)}{2 \pi k_{h} L_{w j} L_{w j}}\right)+\left(\frac{1}{h_{o w j}}\right)}
$$

When both the agitator and the temperature circulator are running (experiments 3-4, Table 2), the forced convection in the fermenter and circulating water in the heating jacket results in the following equation:

$$
U_{w j}=\frac{1}{\left(\frac{A_{o w}^{\prime} \ln \left(\frac{r_{o}^{\prime}}{r_{i}^{\prime}}\right)}{2 \pi k_{w} L_{w j}}\right)+\left(\frac{A_{o w} \ln \left(\frac{r_{o}}{r_{i}}\right)}{2 \pi k_{w} L_{w j}}\right)+\left(\frac{1}{h_{o w j}}\right)}
$$

The heat of mixing $\left(q_{m}\right)$ can be determined by performing a heat balance on the data obtained from experiment 1 . The heat supplied by the circulator $\left(q_{s}\right)$ can be calculated by performing a heat balance on the data obtained from experiments 2, 3 or 4 or calculated from the following equation:

$q_{s}=Q_{s} C_{p s}\left(T_{o}-T_{i}\right)$

Where:

$$
\begin{aligned}
& C_{p s}=\text { specific heat of heating liquid }\left(\mathrm{J} \cdot \mathrm{kg}^{-1} \cdot \mathrm{K}^{-1}\right) \\
& Q_{s}=\text { mass flow rate of heating liquid }\left(\mathrm{kg} \cdot \mathrm{s}^{-1}\right) \\
& T_{i}=\text { inlet temperature of the heating jacket }\left({ }^{\circ} \mathrm{C}\right) \\
& T_{o}=\text { outflow temperature of the heating jacket }\left({ }^{\circ} \mathrm{C}\right)
\end{aligned}
$$

The heat of metabolism can be calculated by performing a heat balance on the data obtained from experiment 5. The values of the various parameters required for the heat balance on the bioreactor system are summarized in Table 3. 
Table 3: Values of the various parameters used in heat balances

\begin{tabular}{lc}
\hline Parameter & Value \\
\hline$A_{b}$ & $0.031 \mathrm{~m}^{2}$ \\
$A_{i w}^{\prime}$ & $0.251 \mathrm{~m}^{2}$ \\
$A_{o c}$ & $0.277 \mathrm{~m}^{2}$ \\
$A_{o w}$ & $0.286 \mathrm{~m}^{2}$ \\
$A_{o w}^{\prime}$ & $0.260 \mathrm{~m}^{2}$ \\
$A_{s}$ & $0.251 \mathrm{~m}^{2}$ \\
$A_{t}$ & $0.031 \mathrm{~m}$ \\
$A_{w}$ & $0.114 \mathrm{~m}{ }^{2}$ \\
$A_{w j}$ & $0.286 \mathrm{~m}$ \\
$C_{p a}$ & $716.000 \mathrm{~J} \cdot \mathrm{kg}^{-1} \cdot \mathrm{K}^{-1}$ \\
$C_{p s}$ & $4175.000 \mathrm{~J} \cdot \mathrm{kg}^{-1} \cdot \mathrm{K}^{-1}$ \\
$d_{b}$ & $0.003 \mathrm{~m}$ \\
$d_{t}$ & $0.023 \mathrm{~m}$ \\
$k_{a}$ & $0.026 \mathrm{~W} \cdot \mathrm{m}^{-1} \cdot \mathrm{K}^{-1}$ \\
$k_{b}$ & $14.6 \mathrm{~W} \cdot \mathrm{m}^{-1} \cdot \mathrm{K}^{-1}$ \\
$k_{h}$ & $0.604 \mathrm{~W} \cdot \mathrm{m}^{-1} \cdot \mathrm{K}^{-1}$ \\
$k_{t}$ & $14.6 \mathrm{~W} \cdot \mathrm{m}^{-1} \cdot \mathrm{K}^{-1}$ \\
$k_{w}$ & $14.6 \mathrm{~W} \cdot \mathrm{m}^{-1} \cdot \mathrm{K}^{-1}$ \\
$L_{b}$ & $0.199 \mathrm{~m}$ \\
$L_{t}$ & $0.199 \mathrm{~m}$ \\
$L_{w}$ & $0.176 \mathrm{~m}$ \\
$L_{w j}$ & $0.402 \mathrm{~m}$ \\
$Q_{a}$ & $5.73 \mathrm{E}-04 \mathrm{~kg} \cdot \mathrm{s}^{-1}$ \\
$Q_{s}$ & $0.014 \mathrm{~kg} \cdot \mathrm{s}^{-1}$ \\
$r_{i}$ & $0.107 \mathrm{~m}$ \\
$r_{i}^{\prime}$ & $0.099 \mathrm{~m}$ \\
$r_{i w}$ & $0.099 \mathrm{~m}$ \\
& $0.113 \mathrm{~m}$ \\
$r_{o}$ & $0.103 \mathrm{~m}$ \\
& $0.103 \mathrm{~m}$ \\
\hline
\end{tabular}

\section{RESULTS AND DISCUSSION}

The average temperatures measured during each experiment are shown in Table 4. The heat balance results for all experiments are shown in Table 5. The temperature, dissolved oxygen, bacteria and jadomycin measurements obtained from experiment 5 are presented in Fig. 4.

Temperature: In the experiments where the water circulator was running (experiments 2, 3, 4 and 5), the bioreactor temperature was successfully maintained at $30^{\circ} \mathrm{C}$. The fluid temperature at the top of the reactor was $1^{\circ} \mathrm{C}$ higher than that at the bottom when the system was agitated. When the system was not agitated, the temperature difference was $4^{\circ} \mathrm{C}$. During the fermentation experiments, there were no differences between the temperatures measured during the growth phase and jadomycin production phase at all locations.

Heat of Mixing: In experiment 1, the system was operated on water (no microbial activity) at room temperature and no air was used. Therefore, the heat generated by metabolism $\left(q_{y}\right)$, the heat supplied by the circulator $\left(q_{s}\right)$ and the heat lost with the exhaust gas $\left(q_{a}\right)$ can be neglected and Eq.1 can be rewritten as follows:

$q_{m}=q_{b}+q_{t}+q_{w j}+q_{w}$

The heat of mixing calculated from Eq.24 was 4.9 $\pm 0.3 \mathrm{~J} \cdot \mathrm{s}^{-1}$. This value was used in heat balance calculations for the other experiments as it was assumed that the rheology of the media would not have a significant effect on the heat balance calculations. The majority of the heat generated by mixing was lost through the walls (93.88\%) while only $2.04 \%$ and $4.08 \%$ were lost through the top and bottom of the reactor.

Heat Provided by the Water Circulator: In experiment 2, no air or agitation were provided while the bioreactor was operating on water (no microbial activity). The water circulator maintained the bioreactor temperature at $30^{\circ} \mathrm{C}$. Therefore, the heat generated by metabolism $\left(q_{y}\right)$, the heat of mixing $\left(q_{m}\right)$ and the heat lost with the exhaust gas $\left(q_{a}\right)$ can be neglected and Eq.1 can be rewritten as follows:

$q_{s}=q_{b}+q_{t}+q_{w j}+q_{w}$

Without the agitator or air operating in the bioreactor, the water circulator supplied $5.6 \pm 0.1 \mathrm{~J} \cdot \mathrm{s}^{-1}$. Of that, $3.57 \%$ was lost from the top of the bioreactor, $5.36 \%$ was lost from the bottom and $91.07 \%$ was lost from the walls.

In experiment 3, air was not provided and the system was operating on water. Therefore, $q_{y}$ and $q_{a}$ can be neglected and Eq.1 can be rewritten as follows:

$q_{m}+q_{s}=q_{b}+q_{t}+q_{w j}+q_{w}$

Data from experiment 3 showed the combined heat gain from mixing and circulator $\left(10.55 \mathrm{~J} \cdot \mathrm{s}^{-1}\right)$. About $2.86 \%$ of the heat was lost from the top of the reactor, $4.78 \%$ was lost from the bottom while $92.36 \%$ was lost from the walls. 
Am. J. Biochem. \& Biotech., 4 (1): 7-18, 2008

Table 4: Average temperatures $\left({ }^{\circ} \mathrm{C}\right)$

\begin{tabular}{|c|c|c|c|c|c|c|c|c|c|c|}
\hline Expt. & $\begin{array}{c}\text { Top Fluid } \\
\qquad T_{e}, T\end{array}$ & $\begin{array}{c}\text { Bottom } \\
\text { Fluid } \\
T_{b}\end{array}$ & $\begin{array}{c}\text { Inlet } \\
T_{i}\end{array}$ & $\begin{array}{c}\text { Outlet } \\
T_{o}\end{array}$ & $\begin{array}{c}\text { Room } \\
T_{a}\end{array}$ & $\begin{array}{c}\text { Fermenter } \\
\text { Wall } \\
T_{\text {ow }}\end{array}$ & $\begin{array}{l}\text { Jacket } \\
\text { Wall } \\
T_{\text {owj }}\end{array}$ & $\begin{array}{l}\text { Lid } \\
T_{o t}\end{array}$ & $\begin{array}{c}\text { Floor } \\
T_{o b}\end{array}$ & $\begin{array}{c}\text { Exhaust } \\
T_{i t}\end{array}$ \\
\hline 1 & $29.5 \pm 0.1$ & $25.1 \pm 0.1$ & $24.7 \pm 0.2$ & $22.3 \pm 0.1$ & $20.8 \pm 0.1$ & $23.4 \pm 0.1$ & $23.8 \pm 0.1$ & $22.0 \pm 0.1$ & $23.3 \pm 0.2$ & $24.6 \pm 0.1$ \\
\hline 2 & $30.6 \pm 0.0$ & $29.5 \pm 0.0$ & $30.7 \pm 0.0$ & $30.7 \pm 0.0$ & $22.1 \pm 0.1$ & $26.3 \pm 0.0$ & $28.5 \pm 0.0$ & $24.4 \pm 0.1$ & $28.6 \pm 0.0$ & $27.4 \pm 0.1$ \\
\hline 3 & $30.8 \pm 0.0$ & $29.9 \pm 0.0$ & $30.8 \pm 0.0$ & $30.8 \pm 0.0$ & $22.4 \pm 0.1$ & $26.9 \pm 0.0$ & $28.7 \pm 0.0$ & $25.3 \pm 0.1$ & $28.3 \pm 0.0$ & $28.1 \pm 0.1$ \\
\hline 4 & $30.8 \pm 0.0$ & $29.8 \pm 0.0$ & $30.7 \pm 0.0$ & $30.7 \pm 0.0$ & $20.7 \pm 0.0$ & $25.7 \pm 0.1$ & $28.5 \pm 0.0$ & $22.9 \pm 0.2$ & $28.4 \pm 0.1$ & $27.3 \pm 0.5$ \\
\hline 5 & $30.4 \pm 0.1$ & $29.9 \pm 0.0$ & $30.2 \pm 0.1$ & $30.3 \pm 0.1$ & $21.9 \pm 0.1$ & $26.0 \pm 0.1$ & $29.7 \pm 0.1$ & $23.6 \pm 0.1$ & $29.3 \pm 0.9$ & $26.8 \pm 0.1$ \\
\hline
\end{tabular}

Table 5: Heat balance results $\left(\mathrm{J} \cdot \mathrm{s}^{-1}\right)$

\begin{tabular}{|c|c|c|c|c|c|c|c|c|c|c|}
\hline \multirow[b]{2}{*}{ Expt. } & \multicolumn{4}{|c|}{ Heat Gains } & \multicolumn{6}{|c|}{ Heat Losses } \\
\hline & $q_{m}$ & $q_{s}$ & $q_{y}$ & Total & $q_{a}$ & $q_{t}$ & $q_{b}$ & $q_{w}$ & $q_{w j}$ & Total \\
\hline 1 & $4.9 \pm 0.3$ & - & - & 4.9 & - & $0.1 \pm 0.0$ & $0.2 \pm 0.0$ & $1.3 \pm 0.2$ & $3.3 \pm 0.1$ & 4.9 \\
\hline 2 & - & $5.6 \pm 0.1$ & - & 5.6 & - & $0.2 \pm 0.0$ & $0.3 \pm 0.0$ & $3.0 \pm 0.1$ & $2.1 \pm 0.0$ & 5.6 \\
\hline 3 & $4.9 \pm 0.3$ & $5.6 \pm 0.1$ & - & 10.5 & - & $0.3 \pm 0.0$ & $0.5 \pm 0.0$ & $4.3 \pm 0.1$ & $5.4 \pm 0.1$ & 10.5 \\
\hline 4 & $4.9 \pm 0.3$ & $10.6 \pm 0.1$ & - & 15.5 & $4.1 \pm 0.0$ & $0.3 \pm 0.0$ & $0.4 \pm 0.0$ & $3.6 \pm 0.2$ & $7.1 \pm 0.0$ & 15.5 \\
\hline 5 & $4.9 \pm 0.3$ & $6.2 \pm 0.5$ & $4.4 \pm 0.3$ & 15.5 & $4.1 \pm 0.1$ & $0.3 \pm 0.0$ & $0.4 \pm 0.0$ & $3.6 \pm 0.1$ & $7.1 \pm 0.1$ & 15.5 \\
\hline
\end{tabular}

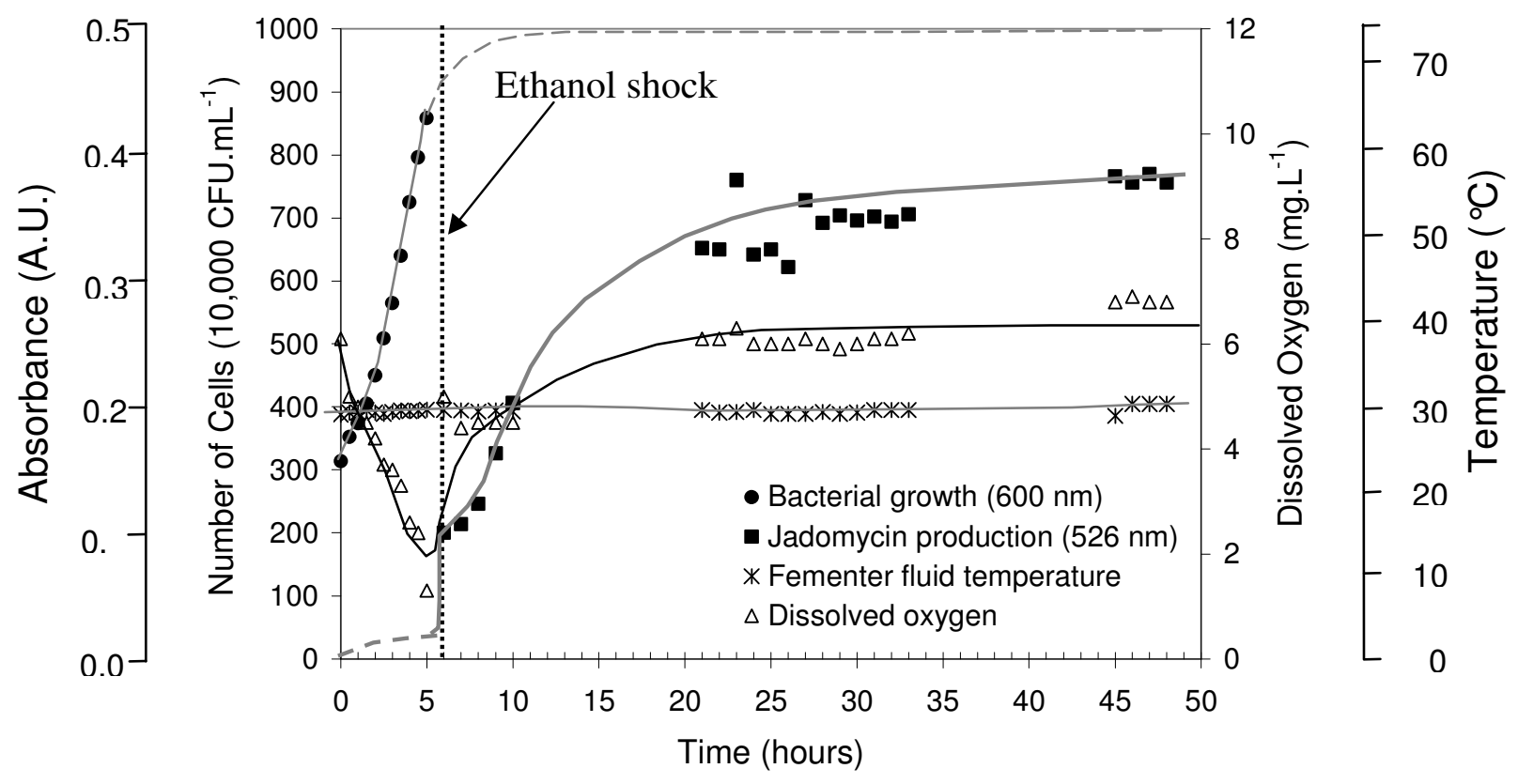

Fig. 4: Bacterial growth, jadomycin production, fluid temperature and dissolved oxygen concentration 
In experiment 4, the air flow, agitation and water circulation were all on and the system operated on water. Therefore, the heat of metabolism $\left(q_{y}\right)$ can be neglected and Eq.1 can be rewritten as follows:

$$
q_{m}+q_{s}=q_{a}+q_{b}+q_{t}+q_{w j}+q_{w}
$$

Data from experiment 4 indicate the heat supplied by the water circulator when air was used increased from $5.6 \mathrm{~J} \cdot \mathrm{s}^{-1}$ to $10.6 \mathrm{~J} \cdot \mathrm{s}^{-1}$. A substantial portion of heat $(26.45 \%)$ was lost with the exhaust air leaving the bioreactor, while $69.03 \%$ was lost through the walls and $1.94 \%$ and $2.58 \%$ were lost through the top and bottom of the bioreactor, respectively.

Heat of Metabolism: In experiment 5, the system operated on production medium for an initial bacterial growth phase of 5 hours followed by a jadomycin production phase. The air supply, agitation and water circulator were all on. Therefore Eq.1 was used to perform the heat balance on the system. The heat provided by the circulator $\left(q_{s}\right)$ was calculated using Eq.23 and the heat of mixing $\left(q_{m}\right)$ was calculated from Eq.24. The results showed that the heat of metabolism was $4.4 \mathrm{~J} \cdot \mathrm{s}^{-1}$. The distribution of heat losses was the same as that of experiment 4 .

Microbial Growth and Jadomycin Production: The bacteria were allowed to grow for the first 5 hours and were then shocked with ethanol. Once the bioreactor was inoculated, microbial growth started and there was no lag period evident. The ethanol shock was administered when the absorbance reading was greater than 0.5 (about $9 \times 10^{6}$ cells $\cdot \mathrm{mL}^{-1}$ ) as recommended by Jakeman et al ${ }^{[6]}$. A specific growth rate, $(\mu)$ of $0.23 \mathrm{~h}^{-1}$ was achieved, which is comparable to the $0.2 \mathrm{~h}^{-1}$ obtained from $S$. coelicolor grown in a bioreactor using minimal media ${ }^{[11]}$. The determination of $\mu$ followed the graphical procedure described by Ghaly et al ${ }^{[12]}$.

After ethanol shock, jadomycin was produced. This was detected by measuring the absorbance of the centrifuged supernatant at $526 \mathrm{~nm}$. Initially jadomycin increased rapidly and reached a maximum level within the first 15 hours after the ethanol shock. This level of jadomycin falls well within the range produced from small scale studies by other researchers summarized by Jakeman et $\mathrm{al}^{[6]}$. The results also indicated that a small amount of jadomycin was produced during the growth phase. This is due to the fact that the bacteria were exposed to the nutrient-deprived production medium, which is different from the growth medium. While small quantities of jadomycin may be produced when $S$. venezuelae ISP5230 is exposed to the nutrient-deprived media, only significant quantities are produced when the bacteria are shocked with ethanol ${ }^{[2]}$.

The following equations can be used to describe the maintenance and growth of S. venezuelae ISP5230 and the production of jadomycin $\mathrm{C}$, using glucose as the carbon substrate and glycine as the amino acid.

(a) Respiration and energy production:

$\mathrm{C}_{6} \mathrm{H}_{12} \mathrm{O}_{6}+6 \mathrm{O}_{2} \rightarrow 6 \mathrm{CO}_{2}+6 \mathrm{H}_{2} \mathrm{O}+\Delta$

Glucose

(b) Growth and reproduction:

$5 \mathrm{C}_{6} \mathrm{H}_{12} \mathrm{O}_{6}+6 \mathrm{NH}_{4}^{+} \rightarrow \underset{\text { Glucose }}{6 \mathrm{C}_{5} \mathrm{H}_{7} \mathrm{O}_{2} \mathrm{~N}}+18 \mathrm{H}_{2} \mathrm{O}+6 \mathrm{H}^{+}$
Cells

(c) Product formation ( $\mathrm{JadC})$ :

$4 \mathrm{C}_{6} \mathrm{H}_{12} \mathrm{O}_{6}+\mathrm{C}_{2} \mathrm{H}_{5} \mathrm{NO}_{2} \rightarrow \mathrm{C}_{26} \mathrm{H}_{23} \mathrm{NO}_{9}+13 \mathrm{H}_{2} \mathrm{O}+4 \mathrm{OH}^{-}$

Glucose Glycine Jadomycin $\mathrm{C}$

Combining the above reactions yields the following overall equation:

$10 \mathrm{C}_{6} \mathrm{H}_{12} \mathrm{O}_{6}+\mathrm{C}_{2} \mathrm{H}_{5} \mathrm{NO}_{2}+6 \mathrm{O}_{2}+6 \mathrm{NH}_{4}^{+} \rightarrow$

$6 \mathrm{C}_{5} \mathrm{H}_{7} \mathrm{O}_{2} \mathrm{~N}+\mathrm{C}_{26} \mathrm{H}_{23} \mathrm{NO}_{9}+41 \mathrm{H}_{2} \mathrm{O}+6 \mathrm{CO}_{2}+2 \mathrm{H}^{+}+\Delta$

From Eq.31, $10 \%$ of the glucose is used for maintenance, $50 \%$ is used for microbial growth, and $40 \%$ is used for product formation. About $0.38 \mathrm{~g}$ of cells and $0.27 \mathrm{~g}$ of jadomycin $\mathrm{C}$ are produced from each gram of glucose.

Dissolved Oxygen: The dissolved oxygen (DO) content in the bioreactor varied during the growth of the $S$. venezuelae ISP5230 and production of jadomycin. Prior to ethanol shock, the DO concentration steadily decreased from 6.1 to $2.0 \mathrm{mg} \cdot \mathrm{L}^{-1}$, corresponding to the exponential growth of bacteria when demand for oxygen would be high. Similar concentrations were observed by Kojima et $\mathrm{al}^{[13]}$, during moranoline fermentation by S. lavendulae. After ethanol shock, the DO concentration started to increase until it reached $6.2 \mathrm{mg} \cdot \mathrm{L}^{-1}$. These results indicate that the growth of the bacteria is severely restricted by the ethanol shock step and that jadomycin production is linked to restricted bacterial growth, supporting the findings from the study by Doull et $\mathrm{al}^{[2]}$. 


\section{CONCLUSIONS}

Jadomycin C was successfully produced from $10 \mathrm{~L}$ of fermentation media in a $19 \mathrm{~L}$ bioreactor using Streptomyces venezuelae ISP5230. The bioreactor temperature was maintained at $30^{\circ} \mathrm{C}$. The heat of mixing from the agitator was $4.9 \mathrm{~J} \cdot \mathrm{s}^{-1}$. The heat of metabolism was $4.4 \mathrm{~J} \cdot \mathrm{s}^{-1}$ and the heat provided by the water circulator was $6.2 \mathrm{~J} \cdot \mathrm{s}^{-1}$ during the fermentation. A substantial portion of heat $(26.45 \%)$ was lost with the exhaust air leaving the bioreactor, while $69.03 \%$ was lost through the walls and $1.94 \%$ and $2.85 \%$ were lost through the top and bottom of the bioreactor. Once the bioreactor was inoculated, there was no lag period evident and a specific growth rate of $0.23 \mathrm{~h}^{-1}$ was achieved. The rate of jadomycin production initially increased rapidly and reached a maximum level within 15 hours after the ethanol shock. The dissolved oxygen (DO) concentration during the experiment was inversely related to the growth of the bacteria.

\section{ACKNOWLEDGEMENTS}

The research was funded by National Science and Engineering Research Council of Canada (NSERC). The initial cultures of Streptomyces venezuelae ISP5230 were obtained from Dr. Jakeman's laboratory, Faculty of Pharmacy, Dalhousie University.

\section{REFERENCES}

1. Zheng, J.-T., U. Rix, L. Zhao, C. Mattingly, V. Adams, Q. Chen, J. Rohr, J. and K.-Q. Yang, 2005. Cytotoxic Activities of New Jadomycin Derivatives. Journal of Antibiotics, 58(6): 405-408.

2. Doull, J.L., A.K. Singh, M. Hoare, and S.W. Ayer, 1994. Conditions for the production of jadomycin B by Streptomyces venezuelae ISP5230: effects of heat shock, ethanol treatment and phage infection. Journal of Industrial Microbiology, 13(2): 120-5.

3. Doull, J.L., S.W. Ayer, A.K. Singh, P. Thibault P., 1993. Production of a novel polyketide antibiotic, jadomycin $\mathrm{B}$, by Streptomyces venezuelae following heat shock. Journal of Antibiotics, 46: 849-871.
4. Jakeman D.L., S. Farrell, W. Young, R.J. Doucet, and S.C. Timmons, 2005a. Novel jadomycins: incorporation of non-natural and natural amino acids. Bioorganic and Medicinal Chemistry Letters, 15: 1447-1449.

5. Jakeman D.L., C.L. Graham, and T.R. Reid, 2005b. Novel and expanded jadomycins incorporating non-proteogenic amino acids. Bioorganic and Medicinal Chemistry Letters, 15: 5280-5283.

6. Jakeman, D.L., C.L. Graham, W. Young, and L.C. Vining, 2006. Culture conditions improving the production of jadomycin B. Journal of Industrial Microbiology and Biotechnology 33(9): 767-772.

7. Rix, U., J. Zheng, L.L. Remsing, U. Rix, L. Greenwell, K. Yang, and J. Rohr, 2004. The dynamic structure of jadomycin $\mathrm{B}$ and the amino acid incorporation step of its biosynthesis. Journal of American Chemistry Society, 126: 4496-4497.

8. Ghaly, A.E. and N.S. Mahmoud, 2002. Influence of ambient air temperature on the cooling/heating load of a single cell protein jacketed fermenter operating on cheese whey under continuous conditions. Biotechnology Progress, 18(4): 713722.

9. Ghaly, A.E. and N.S Mahmoud, 2003. Heat Generated by Mechanical Agitation and Lactose Metabolism during Continuous Propagation of Kluyveromyces fragils in Cheese Whey. Agricultural Engineering International.

10. Holman, J.P. (2002). Heat transfer (9th ed.). Boston: McGraw Hill.

11. Mira de Orduna, R. and U. Theobald, 2000. Intracellular glucose 6-phosphate content in Streptomyces coelicolor upon environmental changes in a defined medium. Journal of Biotechnology, 77: 209-218.

12. Ghaly, A.E., R. Kok and J.M. Ingrahm, 1989. Growth rate determination of heterogeneous microbial population in swine manure. Applied. Biochemistry and Biotechnology, 22: 59-78.

13. Kojima, M., N. Tachikake, Y. Kyotani, K. Konno, S. Maruo, M. Yamamoto and Y. Ezure, 1995. Effect of dissolved oxygen and $\mathrm{pH}$ on moranoline (1-deoxynojirimycin) fermentation by Streptomyces lavendulae. Journal of Fermentation and Bioengineering, 79(4): 391-394. 